\title{
Analisis Faktor-Faktor Yang Mempengaruhi Minat Berwirausaha Mahasiswa Program Studi Pendidikan Ekonomi Fakultas Ilmu Sosial dan Ekonomi Universitas Hamzanwadi
}

\author{
Rohaeniyah Zain ${ }^{1}$ Isfi Sholihah ${ }^{2}$, Ahmad Zainuddin Fikri ${ }^{3}$ \\ ${ }^{1,2}$ Prodi penddikan ekonomi, FISE Universitas Hamzanwadi \\ Email : rohaeniahzain@gmail.com
}

Received: 09 Desember, 2020; Accepted: 23 Desember 2020; Published: 25 Desember, 2020

\begin{abstract}
Abstrak
Penelitian ini bertujuan untuk menganalisis faktor-faktor yang mempengaruhi minat minat berwirausaha mahasiswa Program Studi Pendidikan Ekonomi Fakultas Ilmu Sosial dan Ekonomi Universitas Hamzanwadi. Jenis penelitian ini menggunakan metode kuantitatif. Populasi penelitian ini adalah seluruh mahasiswa Program Studi Pendidikan Ekonomi Univeersitas Hanzanwadi yang berjumlah 408 orang. Dalam penarikan sampel peneliti menggunakan teknik Simple Random Sampling. Teknik analisis data menggunakan Regresi Linear Berganda dan sebagai alat dalam pengolahan datanya yaitu menggunakan program SPSS 16. Hasil penelitian menunjukan bahwa secara parsial dan simultan variabel lingkungan keluarga, pendidikan kewirausahaan dan modal berpengaruh terhadap minat berwirausaha mahasiswa Program Studi Pendidikan Ekonomi Fakultas Ilmu Sosial dan Ekonomi Universitas Hamzanwadi, dan variabel yang memiliki pengaruh paling besar adalah variabel modal.
\end{abstract}

Kata Kunci: Lingkungan Keluarga, Pendidikan Kewirausahaan, Modal, Minat Berwirausaha

\begin{abstract}
This study aims to analyze the factors that influence the interest in entrepreneurship in the Economic Education Study Program of the Faculty of Social and Economic Sciences, Hamzanwadi University. This type of research uses quantitative methods. The population of this study were all students of the Hanzanwadi University Economic Education Study Program, totaling 408 people. In taking the sample, the researcher used the simple random sampling technique. The data analysis technique uses Multiple Linear Regression and as a tool in data processing, namely using the SPSS 16 program. The results show that partially and simultaneously the variables of family environment, entrepreneurial education and capital have an effect on the interest in entrepreneurship in students of the Economic Education Study Program, Faculty of Social and Economic Sciences, University. Hamzanwadi, and the variable that has the greatest influence is the variable capital. Keywords: Capital; Entrepreneurial Interest; Entrepreneurship Education; Family Environment;
\end{abstract}




\section{PENDAHULUAN}

Krisis ekonomi yang terus melanda Indonesia sampai saat ini memberikan dampak yang besar terhadap perkembangan ekonomi serta keadaan hidup masyarakat Indonesia. Salah satu dampak dari krisis ekonomi tersebut adalah semakin sedikitnya lapangan pekerjaan yang tersedia sehingga jumlah pengangguran diindonesia masih sangat banyak. Banyaknya jumlah pengangguuran diIndonesia ini terjadi pada kalangan tidak berpendidikan maupun yang berpendidikan tinggi. Pengangguran yang terjadi pada kalangan berpendidikan tinggi seperti mahasiswa terjadi karena mereka belum siap bekerja.

Dalam hal ini perguruan tinggi sebagai pusat pendidikan dan pengajaran yang diharapkan mampu merubah pola pikir mahasiswa yang selama ini selalu berorientasi menjadi pegawai negeri, ataupun karyawan. Untuk itu kewirausahaan harus diajarkan mulai dari taman kanak-kanak hingga perguruan tinggi utuk menanamkan nilai-nilai kewirausahaan yang akan membentuk karakter dan prilaku untuk kerwirausaha atau memiliki sifat sebagai seorang pengusaha.Dengan diterapkannya nilai-nilai tersebut diharapkan mahasiswa dapat mandiri dalam melakukan pekerjaan atau mandiri dalam berwirausahasehingga mahasiswa yang memiliki jiwa wirausaha dapat menciptakan kesempatan kerja dan dapat membantu pemerintah untuk mengurangi angka pengangguran yang ada di Indonesia maupun lingkungan sekitarnya. Pengangguran diindonesia masih menjadi masalah yang sulit untuk diatasi. Hal ini disebabkan dari banyaknya pelamar pekerjaan dibandingkan lapangan pekerjaan yang ada. Kondisi yang dihadapi ini akan semakin diperburuk jika setiap individu hanya berorientasi sebagai pencari kerja (job seeker) bukan menjadi pencipta pekerjaan (job creator) yang dapat menampung beberapa pegawai melalui wirausaha.

Tabel 1.0: Data Tingkat Pengangguran Terbuka di Indonesia Menurut Provinsi (persen), Februari 2018-Februari 2020

\begin{tabular}{|c|c|c|c|c|c|}
\hline Provinsi & $\begin{array}{c}\text { Februari } \\
2018\end{array}$ & $\begin{array}{l}\text { Februari } \\
2019\end{array}$ & $\begin{array}{c}\text { Februari } \\
2020\end{array}$ & $\begin{array}{l}\text { Perubahan Feb. } \\
\text { 2018-Feb. } 2019\end{array}$ & $\begin{array}{l}\text { Perubahan } \\
\text { Feb. 2019-Feb. } \\
2020\end{array}$ \\
\hline (1) & (2) & (3) & (4) & (5) & (6) \\
\hline
\end{tabular}


Zein..dkk... Analisis Faktor-Faktor Yang Mempengaruhi Minat Berwirausaha Mahasiswa Program Studi Pendidikan Ekonomi

\begin{tabular}{|c|c|c|c|c|c|}
\hline Aceh & 6,55 & 5,53 & 5,42 & $-1,02$ & $-0,11$ \\
\hline Sumatera Utara & 5,59 & 5,56 & 4,73 & $-0,03$ & $-0,83$ \\
\hline Sumatera Barat & 5,55 & 5,29 & 5,22 & $-0,26$ & $-0,07$ \\
\hline Riau & 5,72 & 5,57 & 5,07 & $-0,15$ & $-0,50$ \\
\hline Jambi & 3,65 & 3,62 & 4,41 & $-0,03$ & 0,79 \\
\hline Sumatera Selatan & 4,02 & 3,99 & 3,86 & $-0,03$ & $-0,13$ \\
\hline Bengkulu & 2,70 & 2,50 & 3,22 & $-0,20$ & 0,72 \\
\hline Lampung & 4,33 & 3,96 & 4,28 & $-0,37$ & 0,32 \\
\hline Bangka Belitung & 3,61 & 3,39 & 3,41 & $-0,22$ & 0,02 \\
\hline Kepulauan Riau & 6,43 & 6,41 & 5,57 & $-0,02$ & $-0,84$ \\
\hline DKI Jakarta & 5,34 & 5,13 & 4,93 & $-0,21$ & $-0,20$ \\
\hline Jawa Barat & 8,16 & 7,73 & 7,69 & $-0,43$ & $-0,04$ \\
\hline Jawa Tengah & 4,23 & 4,22 & 4,25 & $-0,01$ & 0,03 \\
\hline D.I. Yogyakarta & 3,06 & 2,86 & 3,38 & $-0,20$ & 0,52 \\
\hline Jawa Timur & 3,85 & 3,83 & 3,69 & $-0,02$ & $-0,14$ \\
\hline Banten & 7,77 & 7,58 & 8,01 & $-0,19$ & 0,43 \\
\hline Bali & 0,86 & 1,19 & 1,21 & 0,33 & 0,02 \\
\hline Nusa Tenggara Barat & 3,38 & 3,27 & 3,14 & $-0,11$ & $-0,13$ \\
\hline Nusa Tenggara Timur & 2,98 & 3,10 & 2,80 & 0,12 & $-0,30$ \\
\hline Kalimantan Barat & 4,15 & 4,14 & 4,56 & $-0,01$ & 0,42 \\
\hline Kalimantan Tengah & 3,18 & 3,33 & 3,39 & 0,15 & 0,06 \\
\hline Kalimantan Selatan & 3,86 & 3,50 & 3,80 & $-0,36$ & 0,30 \\
\hline Kalimantan Timur & 6,90 & 6,66 & 6,88 & $-0,24$ & 0,22 \\
\hline Kalimantan Utara & 4,68 & 5,80 & 5,65 & 1,12 & $-0,15$ \\
\hline Sulawesi Utara & 6,09 & 5,37 & 5,57 & $-0,72$ & 0,20 \\
\hline Sulawesi Tengah & 3,19 & 3,54 & 2,98 & 0,35 & $-0,56$ \\
\hline Sulawesi Selatan & 5,39 & 5,42 & 6,07 & 0,03 & 0,65 \\
\hline Sulawesi Tenggara & 2,79 & 2,96 & 3,17 & 0,17 & 0,21 \\
\hline Gorontalo & 3,62 & 3,47 & 3,59 & $-0,15$ & 0,12 \\
\hline Sulawesi Barat & 2,45 & 1,45 & 2,61 & $-1,00$ & 1,16 \\
\hline Maluku & 7,38 & 6,91 & 7,02 & $-0,47$ & 0,11 \\
\hline Maluku Utara & 4,65 & 5,09 & 4,26 & 0,44 & $-0,83$ \\
\hline Papua Barat & 5,67 & 5,28 & 6,20 & $-0,39$ & 0,92 \\
\hline Papua & 2,91 & 3,42 & 3,62 & 0,51 & 0,20 \\
\hline Total & 5,13 & 5,01 & 4,99 & $-0,12$ & $-0,02$ \\
\hline
\end{tabular}

Sumber: Badan Pusat Statistik (BPS) Indonesia

Menumbuhkan jiwa kewirausahaan pada mahasiswa perguruan tinggi merupakan salah satu alternatif untuk menguranngi pengangguran. Dengan 
memiliki jiwa kewirausahaan, diharapkan mahasiswa dapat menciptakan lapangan pekerjaan. Untuk menciptakan wirausaha-wirausaha baru diperlukan adanya peningkatan kualitas sumber daya manusia. Pengaruh pendidikan kewirausahaan merupakan salah satu faktor penting untuk menumbuhkan dan mengembangkan hasrat, jiwa dan prilaku berwirausaha dikalangan generasi muda. Pihak perguruan tinggi perlu menerapkan pola pembelajaran kewirausahaan untuk membekali mahasiswa dengan pengetahuan yang dapat mendorong semangat mahasiswa untuk berwirausaha. Menumbuhkan jiwa kewirausahaan para mahasiswa perguruan tinggi dipercaya merupakan alternatif jalan keluar untuk mengurangi tingkat pengangguran, karena para sarjana diharapkan wirausahawan muda terdidik yang mampu merintis usahanya sendiri. Namun dalam kenyataannya, masih banyak dari mahasiswa yang menganggap menjadi wirausaha itu kurang menjanjikan kesuksesan dimasa depan bahkan tidak sedikit dari mahasiswa yang mengikuti dan mengerjakan tugas mata kuliah yang berkaitan dengan bisnis hanya sebagai formalitas untuk mendapatkan nilai yang bagus bukan untuk mempersiapkan diri untuk menjadi wirausaha.

Selain itu, banyak mahasiswa maupun lulusan perguruan tinggi yang lebih memfokuskan diri untuk mencari pekerjaan, bukan menciptakan pekerjaan. Bahkan ada juga dari mereka yang menunda kelulusan karena merasa belum siap untuk mendapatkan pekerjaan. Mereka lebih banyak menyiapkan diri untuk mengikuti seleksi penerimaan karyawan dari pada menyiapkan diri untuk membuka usaha baru. Hal demikianlah yang menjadi dasar peneliti tertarik untuk melakukan penelitian.

\section{METODE}

Penelitian ini merupakan penelitian pendekatan kuantitatif. Menurut Siyoto (Siyoto, 2015), penelitian kuantitatif adalah definisi, pengukuran data kuantitatif dan statistic objektif melalui perhitungan ilmiah berasal dari sampel orang-orang atau penduduk yang diminta menjawab atas sejumlah pertanyaan tentang survey untuk menentukan frekuensi dan persentase tanggapan mereka. Penelitian ini dilaksanakan di 
Universitas Hamzanwadi yang beralamat di Jln. TGKH. M. Zainuddin Abd. Madjid Pancor-Selong. Penelitian dimulai pada bulan Juni- Agustus 2020.

Menurut (Sugiyono 2015), populasi adalah wilayah generalisasi yang terdiri atas objek atau subjek yang mempunyai kualitas dan karakteristik tertentu yang ditetapkan oleh peneliti untuk dipelajari dan ditarik kesimpulannya. Populasi Penelitian ini adalah seluruh mahasiswa program studi pendidikan ekonomi FISE Universitas Hamzanwadi angkatan 2016-2019 dengan jumlah 408 orang. Dalam penarikan sampel peneliti menggunakan teknik Simple Random Sampling. Menurut (Sugiyono, 2015), dikatakan simple (sederhana) karena pengambilan anggota sampel dari populasi dilakukan secara acak tanpa memperhatikan strata yang ada dalam populasi itu,cara demikian dilakukan bila anggota populasi dianggap homogen. Sampel dalam penelitian ini adalah mahasiswa Program Studi Pendidikan Ekonomi FISE Universitas Hamzanwadi berjumlah 50 orang. Teknik pengumpulan data yang digunakan, meliputi: Studi Pustaka, Angket atau Kuesioner dan Dokumentasi.

Peneliti menggunakan tekknik analisis data antara lain:

1) Analisis regresi linear berganda

Menurut (Sugiyono, 2015), analisis regresi linier berganda dilakukan Untuk menguji pengaruh variabel bebas (indevenden) baik secara simultan maupun parsial terhadap minat berwirausaha. Adapun formulasi regresi linier berganda dalam penelitian ini adalah sebagai berikut:

$$
\mathrm{Y}=\mathrm{a}+\mathrm{b}_{1} \mathrm{X}_{1}+\mathrm{b}_{2} \mathrm{X}_{2}+\mathrm{b}_{3} \mathrm{X}_{3}+\mathrm{ei}
$$

\section{2) Uji Asumsi Klasik}

Menurut (Ghozali, 2011), uji asumsi klasik adalah model regresi yang diperoleh dari metode kuadrat terkecil biasa (Ordinary Least Squares/OLS), merupakan model regresi yang menghasilkan estimator linier tidak bias yang terbaik (Best Linear Unbias Estimator/BLUE). Kondisi ini akan terjadi jika dipenuhi beberapa asumsi, yang disebut dengan asumsi klasik, yaitu: multikolinearitas, heteroskedastisitas, dan normalitas.

3) Uji T

Analisis ini digunakan untuk menguji pengaruh parsial antara lingkungan keluarga, pendidikan kewirausahaan dan modal terhadap minat berwirausaha. 
4) Uji F

Analisis ini digunakan Untuk menguji pengaruh secara simultan antara lingkungan keluarga, pendidikan kewirausahaan dan modal terhadap minat berwirausaha.

\section{HASIL DAN PEMBAHASAN}

Penelitian ini menggunakan data primer yang dikumpulkan melalui kuesioner dan dibagikan kepada responden penelitian, responden dalam penelitian ini adalah mahasiswa aktif program studi pendidikan ekonomi universitas hamzanwadi yang telah menempuh mata kuliah kewirausahaan yaitu mahasiswa angkatan 2016-2018 yang diambil secara acak oleh peneliti.

\section{1) Hasil Uji Validitas dan Reliabilitas instrumen}

Berdasarkan hasil uji validitas intrumen terdapat 35 item yang valid dan 5 item yang tidak valid. Sedangkan berdasar hasil uji reliabilitas instrumen maka intrumen penelitian dinyatakan reliabel.

\section{2) Hasil Analisis Regresi Linier Berganda}

Tabel 2. Hasil Analisis Regresi Liniear Berganda

\begin{tabular}{|c|c|c|c|c|c|}
\hline \multicolumn{6}{|c|}{ Coefficients $^{\mathrm{a}}$} \\
\hline \multirow[b]{3}{*}{ Model } & Unstan & dardized & Standardized & \multirow[b]{3}{*}{$\mathrm{t}$} & \multirow[b]{3}{*}{ Sig. } \\
\hline & Coef & icients & Coefficients & & \\
\hline & B & Std. Error & Beta & & \\
\hline 1 (Constant) & 22.877 & 3.225 & & 7.094 & .000 \\
\hline Lingkungang keluarga (X1) & .081 & .076 & .171 & 1.066 & .292 \\
\hline $\begin{array}{l}\text { Pendidikan kewirausahaan } \\
\text { (X2) }\end{array}$ & .166 & .083 & .303 & 1.994 & .052 \\
\hline Modal (X3) & .101 & .109 & .154 & .931 & .357 \\
\hline
\end{tabular}

Dari hasil analisis data pada tabel 1.1 diatas menunjukan bahwa hasil analisis persamaan regresi linear bergandanya adalah $\mathrm{Y}=22.877+0.081 \mathrm{X}_{1}+$ $0.166 X_{2}+0.106 X_{3}+$ e. Persamaan tersebut artinya Nilai konstanta sebesar 22.877 yang berarti bahwa jika tidak ada perubahan pada variabel bebas yang terdiri dari variabel lingkungan keluarga, pendidikan kewirausahaan dan modal 
yang mempengaruhi minat berwirausaha maka minat berwirausaha akan mempunyai nilai sebesar 22.877 .

Variabel lingkungan keluarga mempunyai pengaruh yang positif terhadap minat berwirausaha mahasiswa, dengan koefisien regresi sebesar 0.081 yang artinya apabila variabel lingkungan keluarga meningkat, maka minat berwirausaha akan meningkat sebesar 0.081 satuan dengan asumsi bahwa variabel lain dalam kondisi konstan.

Variabel pendidikan kewirausahaan mempunyai pengaruh yang positif terhadap minat berwirausaha mahasiswa, dengan koefisien regresi sebesar 0.166 yang artinya apabila variabel pendidikan kewirausahaan meningkat, maka minat berwirausaha akan meningkat sebesar 0.166 satuan dengan asumsi bahwa variabel lain dalam kondisi konstan.

Variabel modal juga mempunyai pengaruh yang positif terhadap minat berwirausaha mahasiswa, dengan koefisien regresi sebesar 0.106 yang artinya apabila variabel modal meningkat, maka minat berwirausaha akan meningkat sebesar 0.106 satuan dengan asumsi bahwa variabel lain dalam kondisi konstan. Dengan adanya pengaruh yang positif ini, berarti bahwa antara variabel lingkungan keluarga, pendidikan kewirausahaan dan modal menunjukkan hubungan yang searah dengan minat berwirausaha. Jika variabel lingkungan keluarga, pendidikan kewirausahaan atau variabel modal semakin meningkat mengakibatkan minat berwirausaha akan meningkat, begitu pula sebaliknya jika pada variabel lingkungan keluarga, pendidikan kewirausahaan atau variabel modal semakin menurun maka minat berwirausaha akan semakin menurun.

\section{3) Pengaruh Lingkungan Keluarga, Pendidikan Kewirausahaan dan Modal} Secara Parsial Terhadap Minat Berwirausaha pada Mahasiswa Program Studi Pendidikan Ekonomi FISE Universitas Hamzanwadi.

a. Pengaruh Lingkungan Keluarga terhadap Minat Berwirausaha.

Tabel 2 diatas menunjukkan bahwa nilai signifikan pengaruh lingkungan keluarga (X1) terhadap minat berwirausaha (Y) adalah 0.292 > 
0.05. Hasil penelitian menemukan bahwa variabel lingkungan keluarga berpegaruh signifikan positif terhadap minat berwirausaha.

b. Pengaruh Pendidikan Kewirausahaan terhadap Minat Berwirausaha.

Tabel 2 diatas menunjukkan bahwa nilai signifikan pengaruh pendidikan kewirausahaan (X2) terhadap minat berwirausaha (Y) adalah $0.052>0.05$. Hasil penelitian menemukan bahwa variabel pendidikan kewirausahaan berpegaruh signifikan positif terhadap minat berwirausaha.

c. Pengaruh Modal terhadap Minat Berwirausaha.

Tabel 2 diatas menunjukkan bahwa nilai signifikan pengaruh modal (X3) terhadap minat berwirausaha (Y) adalah $0.357>0.05$. Hasil penelitian menemukan bahwa variabel modal berpegaruh signifikan positif terhadap minat berwirausaha.

4) Pengaruh Lingkungan Keluarga, Pendidikan Kewirausahaan dan Modal Secara Simultan terhadap Minat Berwirausaha pada Mahasiswa Program Studi Pendidikan Ekonomi FISE Universitas Hamzanwadi.

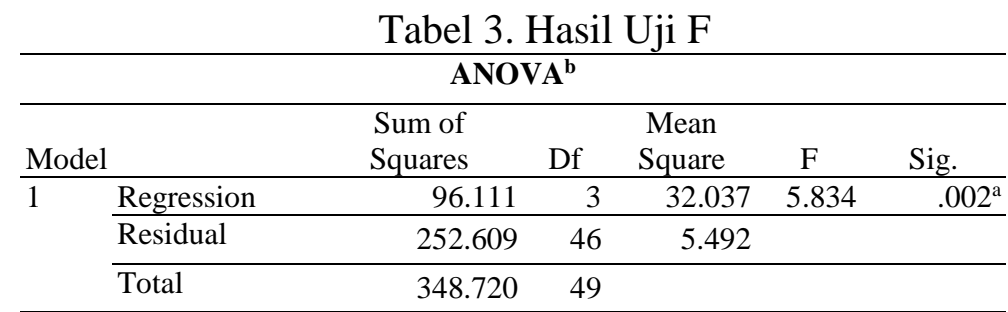

Sumber: data primer yang diolah

Berdasarkan tabel 1.3 diatas diperoleh nilai signifikan $\mathrm{F}$ sebesar 0.002 yang lebih kecil dari 0.05 . Hal ini menunjukkan bahwa variabel lingkungan keluarga, pendidikan kewirausahaan, dan modal secara bersama-sama mempunyai pengaruh yang signifikan terhadap minat berwirausaha

5) Variabel Bebas yang Memiliki Pengaruh Paling Besar terhadap Minat Berwirausaha

Berdasarkan tabel 3 diatas dapat dilihat dari semua variabel bebas yang memberikan pengaruh paling besar terhadap minat berwirausaha adalah variabel modal (X3) dengan nilai signifikan sebesar 0,357. 


\section{KESIMPULAN}

1). Lingkungan Keluarga berpengaruh positif terhadap minat berwirausaha pada Mahasiswa Program Studi Pendidikan Ekonomi FISE Universitas Hamzanwadi dengan nilai signifikan $0.292>0.05$. 2). Pendidikan Kewirausahaan berpengaruh positif terhadap minat berwirausaha pada Mahasiswa Program Studi Pendidikan Ekonomi FISE Universitas Hamzanwadi dengan nilai signifikan $0.052>0.05$. 3). Modal berpengaruh positif terhadap minat berwirausaha pada Mahasiswa Program Studi Pendidikan Ekonomi FISE Universitas Hamzanwadi dengan nilai signifikan $0.357>0.05$. 4).Lingkungan keluarga, pendidikan kewirausahaan dan modal secara bersama-sama berpengaruh secara signifikan terhadap minat berwirausaha pada Mahasiswa Program Studi Pendidikan Ekonomi FISE Universitas Hamzanwadi dengan nilai signifikan F sevesar $0.002<0.05$. 5). Variabel yang memiliki pengaruh paling besar terhadap minat berwirausaha pada Mahasiswa Program Studi Pendidikan Ekonomi FISE Universitas Hamzanwadi adalah variabel Modal dengan nilai signifikan 0.357 .

\section{DAFTAR RUJUKAN}

Al, F. E. (2009). Analisi faktor-faktor yang mempengaruhi minat wirausaha mahasiswa dengan teknik SEM. Matematika UNAND, 1(2).

Alma, B. (2017). kewirausahaan. CV. Alfabeta.

Arikunto, S. (2013). Prosedur Penelitan Suatu Pendekatan Praktik. Rineka Cipta. Asmani, J. M. (2011). Sekolah Entrepreneur. Harmoni.

Basrowi. (2014). Kewirausahaan Untuk Perguruan Tinggi. Ghalia Indonesia.

Conny, S. (2012). Pendidikan Keluarga Dalam Era Global. PT Preenhalindo.

Daryanto. (2012). Pendidikan Kewirausahaan. Gava Media.

Daryanto. (2013). Kewirausahaan. Gava Media.

Djaali. (2013). Psikologi Pendidikan (edisi revisi). Bumi Aksara.

Fadhli, rusydi ananda dan muhammad. (2018). statistik pendidikan (teori dan praktik dalam pendidikan). widy puspita.

Faudi. (2009). Hubungan minat berwirausaha dengan prestasi praktik kerja industri siswa kelas XII teknik otomotif SMK Negeri 1 Adiwerna Kabupaten Tegal. PTM, 9(1).

Ghozali, I. (2011). Aplikasi Analisis Multivariate dengan Program SPSS. Universitas Diponegoro.

Hamdani, M. (2010). Entrepreneurship Kiat Melihat dan Memberdayakan Potensi 


\section{Bisnis. PT BUKU KITA.}

Hardani, A. (2020). Metode penelitan kuantitatif dan kualitatif. Pustaka Ilmu.

Helmawati. (2014). Pendidikan Keluarga Teori dan Praktik. PT Remaja Rosdakarya.

Jamu, M. E. (2018). Analisis Faktor-Faktor Yang Mempengaruhi Minat Berwirausaha Mahasiswa (Studi Kasus Pada Mahasiswa Manajemen Universitas Flores). INOBIS: Jurnal Inovasi Bisnis Dan Manajemen Indonesia, 1(3), 305-317. https://doi.org/10.31842/jurnal-inobis.v1i3.38

Kasmir. (2014). kewirausahaan (edisi revisi). Rajawali Pers.

Khairani. (2013). Psikologi Pembelajaran. Aswaja Persindo.

Kristsada, A. D. (2010). Menumbuhkan Minat Belajar Anak. Tiara Wacana.

Kurniati, E. D. (2018). Kewirausahaan Industri. Deepiblish.

Munib. (2004). Pengantar Ilmu Pendidikan. UPT MK UNNES.

Rahmadi, A. N., \& Heryanto, B. (2017). Analisis Faktor-Faktor Yang Mempengaruhi Minat Berwirausaha Pada Mahasiswa Program Studi Manajemen Fakultas Ekonomi Universitas Kadiri. Ekonika : Jurnal Ekonomi Universitas Kadiri, 1(2), 153-169. https://doi.org/10.30737/ekonika.v1i2.13

Renny, Y., \& Dayat, H. I. (2019). Analisis Faktor - Faktor Yang Mempengaruhi Minat Berwirausaha Di Kalangan Mahasiswa Politeknik Kotabaru. Journal of Chemical Information and Modeling, 5(2), 49-61. https://doi.org/10.1017/CBO9781107415324.004

Riyanto, B. (2010). Dasar-dasar Pembelajaran Perusahaan, ed. 4. BPFE.

Siyoto, S. (2015). Dasar metodologi penelitian. Literasi Media Publishing.

Slameto. (2010). Belajar dan Faktor-Faktor yang Mempengaruhinya. Rineka Cipta.

Sugiyono. (2012). Statistika untuk penelitian. alfabeta.

Sugiyono. (2015). metodologi penelitian \& pengembangan research and development. alfabeta.

Suherman. (2010). Desain Pembelajaraan Kewirausahaan. Alfabeta.

Suryana. (2014). Kewirausahaan Kiat dan Proses Menuju Sukses. Selemba Empat. Syah, M. (2014). Psikologi Pendidikan. PT Remaja Rosdakarya.

Wibowo, A. (2011). Pendidikan Kewirausahaan (Konsep dan Strategi). Pustaka Belajar. 